\title{
THE POLITENESS OF DIRECTIVE SPEECH ACTS IN SATU JAM LEBIH DEKAT ON TV ONE (PRAGMATIC APPROACH)
}

\author{
Nur Aini Syah ${ }^{1}$; Djatmika ${ }^{2}$; Sumarlam $^{3}$ \\ ${ }^{1}$ Program Studi Linguistik, Universitas Sebelas Maret, Surakarta, Indonesia \\ ${ }^{2,3}$ Universitas Sebelas Maret, Surakarta, Indonesia \\ 1'nurainisyah2014@gmail.com; ${ }^{2}$ djatmika@ staff.uns.ac.id; ${ }^{3}$ sumarlam@staff.uns.ac.id
}

\begin{abstract}
This study aims to find out the types of directive speech act and politeness strategies used in Satu Jam Lebih Dekat talk show on TVOne. The method used in this article is descriptive method which describe the data systematically, factually, and accurately. The uninvolved conversation observation technique was used in collecting data in which this means that the present writer does not involve in the dialogues. Meanwhile, for data analysis technique, the present writer used pragmatic competence-in-dividing. The main theory of this article is the pragmatic theory of Searle's Speech Act and Brown and Levinson's Politeness Strategy. The results indicate that the types of directive speech act of Satu Jam Lebih Dekat program are to please, to request, to ask, to order, to invite, to forbid, to convince, to obligate, to show, to hope, to want, to warn, to advise, and to request. In addition, the politeness strategies are bald on record, positive politeness, negative politeness, and off record. The politeness of directive speech acts supports the effectiveness of talk show because of some factors such as types of directive speech act and politeness strategy.
\end{abstract}

Keywords: pragmatics, directive speech act, politeness strategy, talk show

\section{INTRODUCTION}

In Satu Jam Lebih Dekat talk show, host, speaker, and mystery guest, use some speech as a form of communication. This speech includes some suggestions, advices, warnings, or invitations to do something in which called by directive speech act in pragmatic study. According to Searle (1985:52) directive is aimed to produce an effect in the form of the action taken by the hearer, such as ordering, asking, requesting, recommending, and giving advice.

For a conversation to run smoothly and achieve the desired goal, participants must have a shared understanding of the meaning and they must agree to cooperate with one another by respecting each other's view and allowing interlocutors to take their turns in the conversation. To successfully conduct a conversation, participants must display a willingness and ability to collaborate. Successful conversation yields, for each participant, a degree of relational and interactional satisfaction. Successful verbal communication requires one to be able to identify and satisfy the needs of one's fellow 
conversant. To do this, one must be able to take the perspective of the other and adapt one's language to reflect that perspective.

In the realization, speakers of a language consist of heterogeneous community. This results to the diversity of the language. When people interact, they use politeness strategies to soften the threat to each other's face. Politeness strategy is a way to make the speech better. Polite speech would certainly make the hearer feel valued and respected. The speech delivered tries to avoid a rejection from the hearer by preceding it with a preamble. Two different types of politeness are used in interaction; "negative politeness" and "positive politeness". Brown and Levinson (1987) defined negative politeness as "a repressive action addressed to the addressee's negative face: his want to have his freedom of action unhindered and his attention unimpeded, and state that negative politeness is "the most elaborate and the most conventionalized set of linguistic strategies".

Research using politeness especially in pragmatic reviews ever conducted by Nurhayati (2010) entitled "The Realization of Language Politeness In Ronggeng Dukuh Paruk by Ahmad Tohari". This study discusses the realization of speech acts and politeness. That study concluded that the speech act in Dukuh Paruk Ronggeng novel consists of four groups namely assertive illocutionary acts, directive, commissive and expressive and consists of 7 kinds of speech act realization of politeness. The study is likely to lead to the kinds of speech acts and the realization of linguistic politeness in a novel.

Further research using linguistic politeness is also done by Gil, JM (2012) with the title "Face-Threatening Speech Act and Face-Invading Speech Acts: An Interpretation of Politeness Phenomena". In this study discusses politeness strategies used to minimize the burden threatening face, and discuss the speech acts polite and impolite speech acts. The other research conducted by Khorshidi, H.R. (2013) with the title "Politeness in Study Abroad" in his research discusses the concept of politeness as something important in the interaction between students studying abroad.

The politeness of one's speaker can be different from the others based on knowledge and social background of that person. This also apply to the speaker's utterances of Satu Jam Lebih Dekat talk show. Each speaker has its own way or strategy in choosing sentences that will be delivering to the hearer. This strategy makes each of 
speaker different from the others. This is what makes writer interesting to study further about politeness of directive speech act in Satu Jam Lebih Dekat talk show on TVOne. This article focuses on the use of directive speech act, the realization of politeness strategies, and politeness strategies support the effectiveness of that program.

\section{THEORETICAL REVIEW}

Speech act is a branch of linguistics that studies language from the aspect of actual usage. Speech act theory began in Austin lecture at Harvard University in 1955. Austin distinguishes three types of action: (1) Locutionary speech act (an act of saying something). (2) Illocutionary speech act (an act of doing something saying something). (3) Perlocutionary speech act (Rahardi, 2005). The three division of the language act by Austin is also supported by his student John R. Searle. In his book, Speech Act: An Essay in the Philosophy of Language said that there are three types of actions in a talk, they are speech act, proportional act and illocutionary act (Searle, 1969:24). Rahardi (2005: 35) added that there are three types of speech act, those are locutionary speech act (an act of saying something, illocutionary speech acts (act containing meaning) and perlocutionary (expected impact of the speech).

Locution act is a speech act with words, phrases, and sentences, according to the meaning contained by words, phrases, and sentences themselves. The locutionary speech act can be expressed by the phrase (an act of saying something). This speech act is only the form of speech to express something. This locution act does not concern about the speech being delivered by the speakers (Rahardi, 2009:17). In the same opinion with Rahardi, Yule (1996: 83) stated that an illocutionary act is a basic speech act producing a meaningful linguistic expression.

Illocutionary act is an act to do something with the specific intention and function in the real speaking activity. An illocutionary act can be expressed by expression (an act of doing something saying something) (Rahardi, 2009: 17 and 2005: 35). Illocutionary speech act is divided into five sections according to the division of illocutionary acts as quoted by Searle (1985:52) those are assertive, directive, commissive, expressive and declarative; (a) Assertive is a speech act in which the speaker is attached to the truth of the proposition expressed, for example, stating, expressing opinions, reporting. These illocutions tend to be neutral from the side of 
courtesy, (b) Illocutionary directive is aimed at producing an effect in the form of the action taken by the hearer, such as ordering, asking, requesting, recommending, and giving advice, (c) Commissive is illocutionary act in which the speaker slightly gets into a future action, such as promising, offering, and vowing. This Illocutionary type tends to be fun and less competitive, because it does not refer to the speaker interests but the interests of the hearer. (d) Expressive illocution serves to reveal the psychology (mental) of the speaker from the implied condition. (e) Declarative illocution is used to ensure compatibility between the content of proposition and reality, such as baptizing, firing, giving the name, sentencing, and lifting. Yule (2006: 95).

Perlocution act is a speech act that effects or impacts inflicted by the speaker to the hearer, so that the hearer performs an action based on the content of speech. Perlocutionary speech act can be seen from some of the verbs used. Some verbs used are persuade, deceive, push, annoy, frighten, delight, relief, embarrass, attract attention, and so on. Perlocutionary speech act can produce an effect or power of speech to the hearer and make a sense of worry, fear, anxiety, sadness, delight, despair, disappointment, and so on.

Politeness strategy is a way to make the speech better. Polite speech would certainly make the hearer feel valued and respected. To make more polite speech, here are some strategies that can be used. Positive politeness strategy directs speakers to appeal the general purpose and even friendship. The speech delivered tries to avoid a rejection from the hearer by preceding it with a preamble. Brown and Levinson (1987:61) impose limitation on positive politeness as follows: Positive politeness is essentially directed towards positive face of the hearer, which is considered a positive image owned by the hearer. A positive politeness approaches incised impression on partner face that on certain things, speaker also has the same desire with the partner whom he is talking to. In relating to negative politeness, Brown and Levinson offer the following strategies: (1) Giving special attention to the hearer. (2) Exaggerating an interest, approval, and sympathy for the hearer. (3) Increasing the sense of interest to the hearer. (4) Using markers that indicate the identity or similarity of the group. (5) Finding and using the agreement with the hearer. (6) Avoiding conflict. (7) Raising perception of a number of similarities. (8) Making jokes. (9) Making the perception that the speaker understands what the hearer 
wishes. (10) Making offers and promises. (11) Demonstrating a sense of optimism. (12) Attempting to engage in a together activity. (13) Giving and asking for reasons. (14) Offering a reciprocal action. (15) Giving a sympathy (Brown dan Levinson, 1987:103 129).

Negative politeness strategy is used in the form of the questions that contain an auxiliary verb regarding to feelings. The use of this strategy also results the expressions of apology. Negative politeness strategy can sometimes also be seen from an extended speech. Negative politeness is also specifically expressed in the questions as the question that seems to ask for permission. Like positive politeness, Brown and Levinson also provide some strategies on negative politeness. (1) Expressing indirectly by convention. (20 Using questions with specific particle form. (3) Do not be too optimistic. (4) Reducing the threat the hearer face. (5) Giving respect. (6) Using an apology. (7) Do not mention the interests of the speaker and hearer. (8) Stating the face threatening act as a public social provision. (9) Counting question. (10) Stating clearly if the speaker has kindness to the hearer or not. To express a desire, a person does not always express his desire verbally. The wishes can be expressed with "cues" called indirect action or speech. The success of these cues must also respect the customs that occur in the community.

Bald on record strategy is the opposite of Off Record strategy. In this strategy, the speaker express his intention directly. These directed speech forms are certainly a direct speech without further ado. The forms of Bald on Record may be followed by statements such as silahkan and maukah Anda serving to smoothen the speech. This strategy is often used in imperative speech, but not all imperative speeches use this strategy. This is because the direct command of speech typically occurs among friends. However in emergency situations, this strategy can be used without the need to see who the partner is. In a society, this strategy can be associated with events when speaker has an authority over the hearer. In another sense, this strategy is related to social distance scale.

\section{METHODOLOGY}

This study uses qualitative method so that the data obtained are not stated in the form of numbers or statistics, but in the form of qualitative expressed in words. 
Qualitative study is to describe the meaning of data or phenomena that can be captured by researchers with the demonstrated evidence. Sudaryanto (1993:62) described the concept of the method into three types, descriptive, comparative, and structural. In this study, the writers use a descriptive concept.

The writers use descriptive concept because the study conducted does not consider the truth or falsity of speeches used by speakers. Sudaryanto (1993: 133-135) stated that data collection techniques are divided into basic and advanced techniques. There is only one basic technique (called as a method) referring to the hearing method, but there are some other advanced techniques. Advanced techniques of the hearing methods refer to techniques such as free- involved- technique and a recording technique. Furthermore, Mahsun (2012:93) wrote that in the techniques of freeinvolved-technique, researchers only role as observers. In this technique, researchers were unable to contribute to bring up the data. Researchers just listen the dialogues occur. The recording technique can be performed when the hearing technique of freeinvolved speech done. In this study the hearing technique of free-involved speech is used to listen to speech in a proposing video that is also used as data source. The recording technique is done by recording the record transcript and reflective notes that have been prepared. Recording can be done immediately when the first and the second technique are being done or can be done afterwards (Sudaryanto, 1993:135).

\section{FINDINGS AND DISCUSSIONS}

It has been explained before that the directive speech act is an illocutionary act that aimed at producing an effect in the form of the action taken by the hearer, such as ordering, asking, requesting, recommending, and giving advice. Then politeness strategy is a way of the speaker to make his speech polite and appreciated. In this regard, the following is a discussion of politeness strategies of illocutionary speech act in Satu Jam Lebih Dekat talk show on TV One.

Table 1: The Result of Using Directive Speech Act of Satu Jam Lebih Dekat Talk Show

\begin{tabular}{|l|l|l|l|}
\hline No & \multicolumn{1}{|c|}{ Types of Expressive Speech Act } & Amount & \multicolumn{1}{c|}{ Percentage } \\
\hline 1. & To please & 18 & $1,9 \%$ \\
\hline 2. & To request & 27 & $2,9 \%$ \\
\hline 3. & To ask & 698 & $75,2 \%$ \\
\hline
\end{tabular}




\begin{tabular}{|l|l|l|l|}
\hline 4. & To order & 42 & $4,5 \%$ \\
\hline 5. & To invite & 34 & $3,6 \%$ \\
\hline 6. & To forbid & 17 & $1,8 \%$ \\
\hline 7. & To convince & 25 & $2,7 \%$ \\
\hline 8. & To obligate & 21 & $2,3 \%$ \\
\hline 9. & To show & 10 & $1,1 \%$ \\
\hline 10. & To hope & 9 & $1 \%$ \\
\hline 11. & To want & 10 & $1,1 \%$ \\
\hline 12. & To warn & 7 & $0,7 \%$ \\
\hline 13. & To advise & 6 & $0,6 \%$ \\
\hline 14. & To request & 4 & $0,4 \%$ \\
\hline \multicolumn{2}{|l|}{ Total } & 928 & $100 \%$ \\
\hline
\end{tabular}

Table 1 shows the type of directive speech act of Satu Jam Lebih Dekat Talk Show. The most frequent of type of directive speech act used in Satu Jam Lebih Dekat Talk Show is to ask something.

Table 2: The Realization of Using Politeness Strategy of Satu Jam Lebih Dekat Talk Show

\begin{tabular}{|l|l|l|l|}
\hline \multicolumn{1}{|c|}{ No } & \multicolumn{1}{|c|}{ Politeness Strategies } & \multicolumn{1}{c|}{ Amount } & \multicolumn{1}{c|}{ Percentage } \\
\hline 1. & Bald on record & 20 & $2,2 \%$ \\
\hline 2. & Positive Politeness-attend to hearer & 8 & $0,9 \%$ \\
\hline 3. & Positive Politeness-intensify interest & 50 & $5,4 \%$ \\
\hline 4. & Positive Politeness-use group identify marker & 98 & $10,6 \%$ \\
\hline 5. & Positive Politeness-seek agreement & 389 & $42 \%$ \\
\hline 6. & Positive Politeness-avoid disagreement & 37 & $4 \%$ \\
\hline 7. & Positive Politeness-assert speaker's knowledge & 23 & $2,5 \%$ \\
\hline 8. & $\begin{array}{l}\text { Positive Politeness-include both speaker and } \\
\text { hearer in activity }\end{array}$ & 15 & $1,6 \%$ \\
\hline 9. & Positive Politeness-give or ask reasons & 109 & $11,7 \%$ \\
\hline 10. & Positive Politeness-give gifts & 13 & $1,4 \%$ \\
\hline 11. & Negative Politeness-be conventionally indirect & 3 & $0,3 \%$ \\
\hline 12. & Negative Politeness-question, hedge & 1 & $0,1 \%$ \\
\hline 13. & Negative Politeness-give deference & 19 & $2 \%$ \\
\hline 14. & $\begin{array}{l}\text { Negative Politeness-impersonalize speaker and } \\
\text { hearer }\end{array}$ & 1 & $0,1 \%$ \\
\hline 15. & Off record-give hints & 89 & $9,6 \%$ \\
\hline 16. & Off record-give association clues & 53 & $5,7 \%$ \\
\hline Total & 928 & $100 \%$ & \\
\hline
\end{tabular}

Table 2 shows the realization of politeness strategy of directive speech act in Satu Jam Lebih Dekat Talk Show. The most frequent of politeness strategy used in Satu Jam Lebih Dekat Talk Show is Positive Politeness-seek agreement. The data analysis based on the classification of table 1 and 2 as follow: 


\section{Types of Directive Speech Act}

\section{a. Type of Directive-To please or invite}

Type of directive speech act-to please is inviting someone with respect. The data analysis can be seen in the following exposures:

\section{(1) The context of the speech:}

This occurs when the speech Indy Rahmawati (host) gave a surprise in the form of a large box to Mr. Rizal Ramli and invited Rizal Ramli to open it.

\section{Forms of speech:}

\begin{tabular}{lrl} 
Indy Rahmawati & $:$ Anything else that you want to show this to the Mr \\
Rizal Ramli & $:$ & Rizal Ramli, well please the torn it! (146 \\
Indy Rahmawati & $:$ & Okey immediately torn it \\
Rizal Ramli & $:$ & Chessboard \\
Indy Rahmawati & $:$ & Well, what is the story about chess? (149) \\
\multicolumn{1}{l}{ (146/SJLD-RR/TTD type-to please/1 Januari 2016) }
\end{tabular}

The type of directive speech act-to please in the data (146) is marked using "please" words. The word 'please' is as the form of a lingual marker of inviting someone to do something.

\section{b. Type of Directive-to request}

Request can be interpreted as an act of speaking in order to get something. Type of directive speech acts 'ask' aims for speakers to get something from the hearer. The data analysis can be seen in the following exposures:

\section{(2) The context of the speech:}

The conversation took place between Indy Rahmawati (host) with Tjahyo Kumolo and mystery guest Yon Koeswoyo. Indy Rahmawati request for Koes plus a song. Then they were sang together and accompanied by Yon Koeswoyo's guitar.

\section{Forms of speech:}

Indy Rahmawati : Koes plus song on that time, my request (he he he) (155)

Tjahyo Kumolo : There in my house sometimes I sleep, Above the dusty town hoo hoo

: These memories sis, when I was child want to watch 
a WOD Gandul suklow in Semarang

(155/SJLD-TK/TTD Type-to ask/12 Februari 2016)

Speech data (155) submitted by Indy Rahmawati (host), including the type of TTD 'ask'. It showed on Indy Rahmawati speech "Koes plus song on that time, my request (he he he) (155). The word 'request' to be a lingual marker of directive speech acts.

\section{c. Type of Directive-to ask or asking}

Asking is an action to request for information (descriptions and so on). Directive speech act 'ask' is a speech act performed by the speaker to the hearer to request information or clarification on the subject. The data analysis can be seen in the following

exposures:

\section{(3) The context of the speech:}

The conversation took place between Indy Rahmawati (host) with Retno Marsudi (speakers). At the beginning of Talk Show Indy Rahmawati deliver a quick profile of the speaker (Retno Marsudi). The host (Indy Rahmawati) does not forget to ask about the Retno Marsudi condition.

\section{Forms of speech:}

Indy Rahmawati : $\quad$ Satu Jam Lebih Dekat now, is different from usual because I was in the lobby of the Pancasila foreign ministry building. And our guest this time was Retno Marsudi. The minister of foreign country. how are you mother? (001)

Retno Marsudi : There in my house sometimes I sleep, Above the dusty town hoo hoo

Good. How are you mrs Indy? (002)

(002/SJLD-RR/TTD type-asking bertanya/1 Januari 2016)

(003/SJLD-RR/TTD type-asking bertanya/1 Januari 2016)

The data number (001) delivered by Indy Rahmawati (host), including the type of TTD type 'ask'. The word 'what' to be a lingual marker of directive speech acts in the form of asking. This utterances show that the host wanted to ask the speaker's news and condition.

\section{d. Type of directive speech act-to command or reigning}

Reigning have the meanings given orders; told to do something. The data

analysis can be seen in the following exposures: 


\section{(4) The context of the speech:}

The conversation took place between Indy Rahmawati (host) with Rizal Ramli (speakers). Indy Rahmawati shows incomplete picture and command to Mr Rizal Ramli to guess who is pictures orphotos above.

\section{Forms of speech:}

Indy Rahmawati : $\quad$ There should be look at this view. (046) This is a Rizal Ramli : : Okey

Indy Rahmawati Already able to read who is he? (048) It may seem or not Mr? (049)

Rizal Ramli : : Okey

(047/SJLD-RR/ TTD type-commanding /1 Januari 2016)

The data number (047) delivered by Indy Rahmawati (host), including the type of TTD type 'commanding'. The utterance of Indy Rahmawati "This is a picture, guess it!" The word 'guess' is as lingual marker of directive speech acts in the form of speech reign. Through these utterances show that the host wants to give command to Mr Rizal Ramli to guess what the picture is.

\section{The Realization of Politeness Strategy}

\section{a) Direct Politeness (Bald On-record)}

Direct strategy is a strategy of politeness that is used when the speaker's wishes to do face threatening act in maximum efficiency exceeds the hearer's desire (Brown and Levinson, 1987: 94- 95). The data indicate a direct politeness strategies (Bald Onrecord) can be seen in the following data.

(1) The context of the speech:

The conversation took place between Indy Rahmawati (host) and Tjahyo Kumolo (speakers). Indy Rahmawati asks where a place to put his guitar? Then Mr Tjahyo Kumolo ordered to put the guitar near his seat.

\section{Forms of speech:}

Indy Rahmawati : $\quad$ Okay, it was already mention some group including Koes plus group. Can I put that guitar? Where I should go? 153)

Tjahyo Kumolo : $\quad$ Put it there! (154)

Indy Rahmawati : $\quad$ Put it okey 
(154/SJLD-TK/ TTD type-commanding /12 Februari 2016)

In the conversation number (154) there is a direct politeness strategy (bald on record). Direct politeness strategy used to refer to the speaker's wishes to do face threatening act in maximum efficiency exceeds the hearer's desire. It is deliver by $\mathrm{Mr}$ Tjahyo Kumolo with the sentences "Put it there!". It is as the lingual marker of their politeness strategies (bald on record).

\section{b) Positive Politeness-use group identify marker}

Positive politeness is directly aimed at the hearer's positive face (Brown and Levinson, 1987:101). The data indicate a positive politeness-use group identify marker can be seen in the following data.

\section{(2) Context of speech:}

The conversation took place between Indy Rahmawati (host) with Rizal Ramli (speakers). Indy Rahmawati shows enclosed photo. Indy asks Mr. Rizal to guess whose picture and how the stories happened.

\section{Forms of speech:}

$\begin{array}{lll}\text { Indy } & : & \text { There should be seen Mr, on this view. (046) This is } \\ \text { Rahmawati } & & \text { a picture guest it! (047) } \\ \text { Indy } & \text { look back if can't seen! (050) already imagine in your } \\ \text { Rahmawati } & \text { mind Sir? (051) }\end{array}$
(046/SJLD-RR/TTD type asking/1 Januari 2016) (051/SJLD-RR/TTD type asking/1 Januari 2016)

In conversation the data (051) are positive Politeness -using a marker of group identity. This shows that the hearer desire of politeness regarded as something that is also wanted by the speaker, what is desired by the hearer is also something to be desired by the speakers. It is showen in the speech data is (051) submitted by Indy Rahmawati "already imagine Mr? (051). The word 'sir' is a marker of group identity of married man. This speech included in TTD type 'asking'. 


\section{c) Positive Politeness -seek agreement}

Positive politeness is aimed at the hearer positive face (Brown and Levinson, 1987: 101). The data indicate a positive politeness-use group identify marker can be seen in the following data.

(3)The context of speech: The conversation took place between Indy Rahmawati (host) with Tjahyo Kumolo (speakers) and also Yon Koeswoyo. Indy Rahmawati inquire and praised the meeting with idol is like a dream.

\section{Forms of speech:}

Indy Rahmawati : $\quad$ Back to Mr Tjahyo this meeting like a dream or not? (169) just said before that this meeting just like a dream, this meeting like a dream? (170)

Tjahyo Kumolo : : last time I hunt for tickets

Indy Rahmawati : $\quad$ And watch the idol, right? (171)

Tjahyo Kumolo : : until Histora at the last time

(169/SJLD-TK/TTD type-asking/12 Februari 2016)

(171/SJLD-TK/TTD type-asking/12 Februari 2016)

In conversation the data (169) and (171) are positive Politeness -looking approval. This shows that the desire of hearer regarded as something that is also wanted by the speaker. It is delivered by Indy Rahmawati "and watch the idol, right? (171)”. Its speech became a lingual marker of positive politeness strategy - seeking approval. The word "right?" is a marker of seeking approval. This speech includes TTD type-asking.

\section{d) Positive Politeness-Ask Reason}

Positive politeness is directly aimed at the positive hearer face (Brown and Levinson, 1987:101). The data indicate the positive politeness strategy ask the reason can be seen in the following data.

\section{(4) The context of speech:}

The conversation took place between Indy Rahmawati (host) with Tjahyo Kumolo (speakers). Indy Rahmawati ask about the tiger statues. Then Indy asked about who is waiting and keeping the statues. Indy also ask why the number of statue should be five.

\section{Forms of speech:}

Indy Rahmawati : On the back is also still there, get into the middle of the room there's a tiger, tiger statues. (130) Is there a 


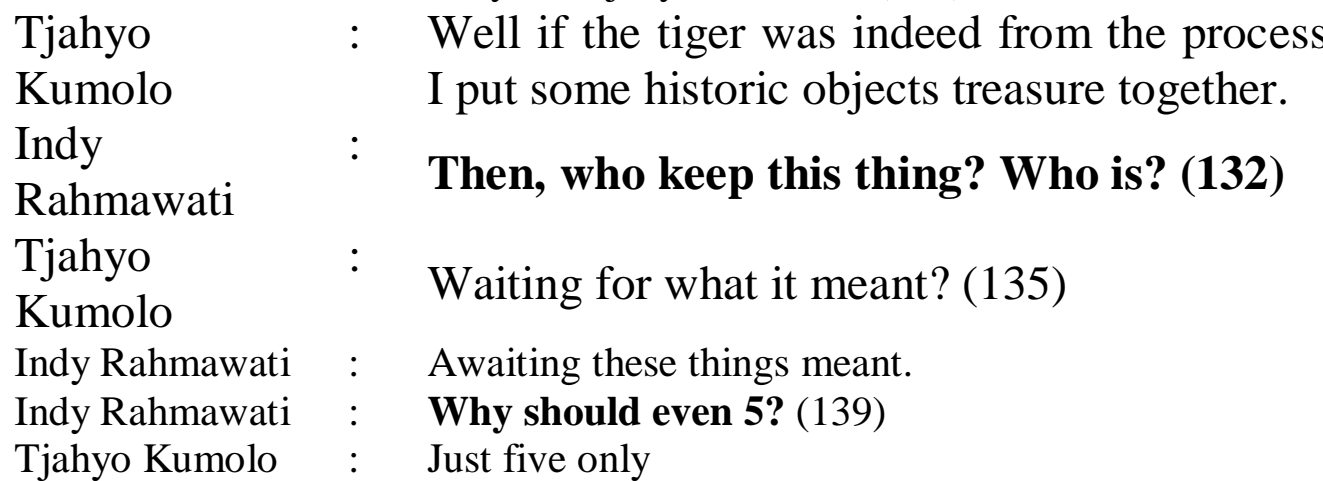

story Mr Tjahyo Kumolo? (131)

(132/SJLD-TK/TTD type-asking/12 Februari 2016)

(135/SJLD-TK/TTD type-asking/12 Februari 2016)

In conversation the data (132) and data (135) contained Positive Politeness leave questions or ask for a reason. This politeness shows that the desire of speakers to provide questions or ask forreasons to hearer. It is delivered by Indy Rahmawati "then, who keep this thing? Who is? (132) (132)". Conversations (132) these speakers provide questions to the hearer with the aim to provide advice indirectly to the hearer. Suggestions in question are to find a place to store these statues. Suggestions indirect form of the question is what a form of positive politeness is. The data (135) as submitted by Indy Rahmawati is "Why should even 5?" This speech also contains the intention of seeking reasons as well as providing advice indirectly. Utterances (132) and (135) included in the TTD type-'ask'.

\section{CONCLUSIONS AND SUGGESTION}

Based on the data classification and analysis, the types of speech act used in Satu Jam Lebih Dekat Talk Show are directive- to please, to request, to ask, to order, to invite, to forbid, to convince, to obligate, to show, to hope, to want, to warn, to advise, and to request. The most dominant use of sub-directive speech act is to ask with the 75 , $2 \%$.

For the realization of the politeness strategy in the directive speech act of Satu Jam Lebih Dekat Talk Show according to Brown and Levinson (1987) are bald on record, positive politenessattend to hearer his interest, wants, needs, and goods, positive politeness intensify interest to hearer, positive politeness-use in group identity markers, positive politeness-seek agreement, positive politeness-avoid disagreement, positive politeness-assert or presuppose speaker's knowledge and concern for hearer's want, 
positive politeness-include both speaker and hearer in the activity, positive politenessgive or ask for reasons, positive politeness-give gifts to hearer, negative politeness-be conventionally indirect, negative politeness-question, hedge, negative politeness-give deference, negative politeness-impersonalize speaker and hearer, off record-give hints, and negative politenessgive association clues. The most dominant use of politeness strategy is positive politeness-asking an agreement.

The politeness of directive speech acts supports the effectiveness of talk show because of some factors which is influence such as sub-directive speech act to please, to request, to ask, to order, to invite, to forbid, convincing, to obligate, to show, to give, to hope, to want, to warn, to advise, to request, and to permit. The other factor is politeness principle and politeness scale supported to this talk show such as tact maxim, generosity maxim, approbation maxim, modesty maxim, agreement maxim, sympathy maxim, cost benefit scale, optionally scale, indirectness scale, authority scale and social distance scale. The other factor is the use of some politeness strategies which minimalize face threatening act. The use of sub-directive speech act, politeness principle, and politeness strategies support the effectiveness of talk show from the receiver, the content, the time, media, form, source, cognitive, affective and conative effect.

Some limitations for this study related to the topic discussed in this article are as follow: (1) this article only focuses on the use of directive speech act and the realization of politeness strategies. Thus, for the future study, it can study the speech act as a whole aspect, (2). This research studies the speech act of Satu Jam Lebih Dekat talk show from pragmatic point of view. In the future, it is suggested that it can be studied by focusing on its style of language.

\section{REFERENCES}

Brown, P., \& Levinson, S. (1987). Politeness some universals in language usage. Cambridge: Cambridge University Press.

Fotouhi, F., \& Ziyaei, F. (2015). The role of politeness strategies in writing emails. Iran: Indian Journal of Fundamental and Applied Life Scieces, vol. 5, no. 1, hlm 52945298.

Gil, J.M. (2012). Face-Threatening speech act and face-invading speech act: an interpretation of politeness phenomena. Argentina: International Journal of Linguistics, vol. 4, no.2, hlm 400-411. 
Grice, H.P. (1989). Studies in the way of words. England: Harvard University Press.

Gunarwan, A. (2007). Implikatur dan kesantunan berbahasa: tindak tutur dan kesantunan berbahasa: beberapa tilikan sandiwara ludruk dalam Yassir Nasanius (Peny). PELLBA 18. Jakarta: Pusat Kajian Bahasa Dan Buadya Unika Atma Jaya.

Leech, G. (2015). Prinsip-prinsip pragmatik (Terjemahan oleh M.D.D Oka). Jakarta: UI Press.

Mahsun. (2012). Metode penelitian bahasa. Jakarta: PT Raja Grafindo Persada.

Moleong, L.J. (2015). Metodologi penelitian kualitatif. Bandung: PT Remaja Rosdakarya.

Rahardi, K. (2005). Pragmatik: kesantunan imperatif bahasa Indonesia. Jakarta: Erlangga

Rahardi, K. (2009). Sosiopragmatik kajian imperatif dalam wadah sosiokultural dan konteks situasionalnya. Jakarta: Penerbit Erlangga.

Santosa, R. (2014). Metode penelitian kualitatif kebahasaan. Surakarta: Universitas Sebelas Maret.

Searle, J.R. (1969). Speech act an essay in the philosophy of language. Cambridge: Cambridge University Press.

Searle, J.R. (1985). Foundations of illocutionary logic. Cambridge: Cambridge University Press.

Spradley, J.P. (2007). Metodologi etnografi. Yogyakarta: Tiara Wacana

Sudaryanto. (1993). Metode dan aneka teknik analisis bahasa: pengantar penelitian wahana kebudayaan secara linguistik. Yogyakarta: Duta Wacana University Press.

Sulaiman, M., \& Khoshaba, L. (2016). Speech act as a basic of understanding dialogue coherence with reference to English-Arabic Translation. Macedonia: International Jurnal of Social Science and Humanities, vol. 1, no. 1, hlm 68-98

Timberg, B. (2004). Television a history of the TV talk show. USA: University of Texas Press

Tripp, S.E., Guo, J., \& Lampert, M. (1990). Politeness and Persuasion in Children's Control Acts. North-Holland: Journal of Pragmatic, vol. 14, hlm 307-331.

Yule, G. (1996). Pragmatics. Oxford: Oxford University Press 
Yuliana, R., Rohmadi, M., \& Suhita, R. (2013). Daya Pragmatik Tindak Tutur Dalam Pembelajaran Bahasa Indonesia pada Siswa Sekolah Menengah Pertama,

Basastra: Jurnal Penelitian Bahasa, Sastra Indonesia dan Pengajaranya, vol. 2, no. 1, hlm 1-14.

Zhao, Y., \& Throssell, P. (2011). Speech Act Theory and Its Application to EFL Teaching in China. Tasmania: The International Journal-Language Society and Culture, issue. 32, hlm 88-95. 